\title{
Microbial features of newly-formed soils of disposal fields from sugar refineries
}

\author{
Pavel Mikheev ${ }^{1}$, Igor Zamotaev ${ }^{2 *}$, and Natalia Telnova ${ }^{2}$ \\ ${ }^{1}$ Erisman Federal Research Center of Hygiene, Service for Consumer Rights Protection and Human \\ Welfare (Rospotrebnadzor) 141014, Moscow Region, Russia \\ ${ }^{2}$ Institute of Geography, Russian Academy of Sciences, 119017 Moscow, Russia
}

\begin{abstract}
Newly-formed soils of wastewater disposal fields from two sugar refineries in forest-steppe zone (Kursk region, European Russia) were studied. Among factors of soil formation on sugar wastewater lagoons the geochemical influence of wastewater mixed with diluted filtration and transport-washing sludge stands out. We have revealed key physico-chemical and microbiological properties of such soils formed under different moisture regimes, substrates, vegetation, and duration of use. Compared to conditionally background soils (Luvic (Anthric) Chernozems), the newly formed soils show shift of $\mathrm{pH}$ values to alkaline ones, carbonation, increase of soil organic carbon, growth in mobile forms of phosphorus, potassium and nitrogen. Microflora in studied soils is identical in composition to background soils, but it differs significantly in structure. In soils formed in the decommissioned wastewater lagoons of an active sugar refinery, a higher number of bacteria with low participation of Micromycetes and Actinomycetes was noted, which indicates active destruction of organic matter. In soils of the recultivated and completely abandoned sugar wastewater lagoons indicated as Calcaric Someric Phaeozem, a higher number of Actinomycetes was noted than in the background soils.
\end{abstract}

\section{Introduction}

Disposal fields from sugar refineries, widely represented in the forest-steppe zone of European Russia, are specific anthropogenic landscapes whose spatiotemporal structure is formed mainly under the influence of seasonal technological cycles of sugar production. Complexes of active and abandoned wastewater lagoons of these disposal fields occupy significant areas (up to $3 \mathrm{~km}^{2}$ ), and are often spontaneously used for local agricultural production, storage of municipal waste, etc. The objects of the present study are the newly formed soils of disposal fields from two sugar refineries in Kursk region, central part of European Russia (Fig.1): the currently operating sugar refinery in the town of Lgov and closed in the late 1990s Peny's refinery in the settlement named after Karl Liebknecht (Kurchatov district, Kursk region).

* Corresponding author: zamotaev@,igras.ru 


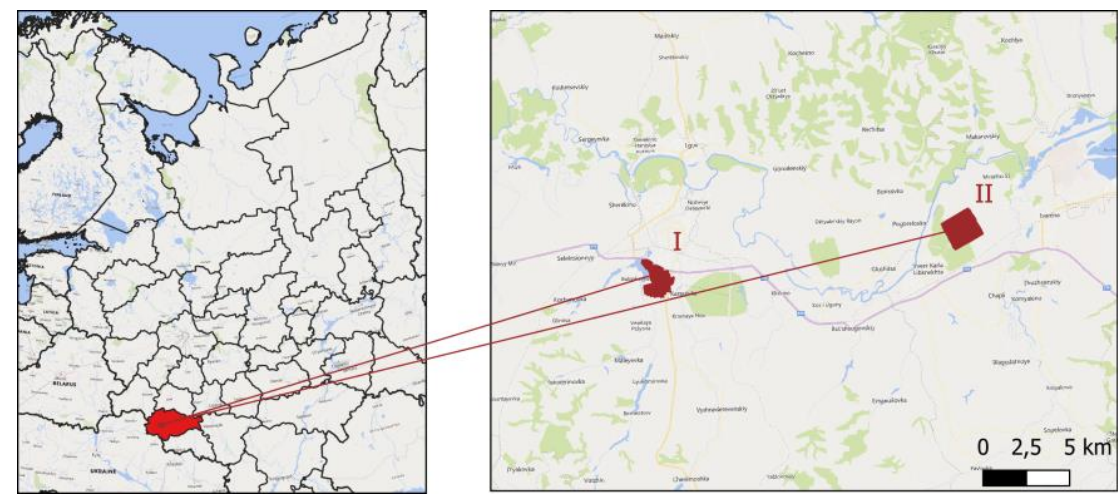

Fig. 1. Location of study areas: I - disposal fields from operative sugar refinery in Lgov; II - disposal fields from abandoned Peny's sugar refinery.

Microbial activity in soil is important for the reliable functioning of soil and its associated ecosystem services. According to the current approach, soil quality assessment methods should focus more on soil microbial functions [1]. Particular attentionin in our research is paid to the properties and peculiarities of such newly formed soils and the composition of their microflora in comparison with the background soils, which are typical for the European forest-steppe.

\section{Materials and methods}

Our field studies were conducted in August - September of 2020 at four key plots in the bottoms of sugar wastewater lagoons, different in duration and periodicity of use for sewage disposal, degree of moisture and type of water regime, substrates, composition of plant communities. In addition, to characterize the background soils of the study area, soil profile under the perennial fallow was studied. The description of the soil profiles was accompanied by field sampling for determining the physical, chemical, and biological properties of soils.

In laboratory the soil carbon and nitrogen contents were analyzed by dry combustion on a Vario Isotope CNSH analyzer; $\mathrm{pH}\left(\mathrm{H}_{2} \mathrm{O}\right)$ was measured by potentiometric method. Content of carbonates $\left(\mathrm{CO}_{2}\right)$ content was evaluated by the Kozlovsky method.

To quantify the amount of microorganisms in surface soil horizons diluted soil suspension was sown on Petri dishes with nutrient agar from fishmeal hydrolyzate. Total amount of bacteria is enumerated for potentially pathogenic bacteria with high growth rate, grown for 24 hours in a thermostat at $37^{\circ} \mathrm{C}$. Amount of Actinomycetes were calculated on starch-ammonia agar, and amount of Micromycetes - on Czapek medium.

Additionally, the quality of wastewater from operational sugar refinery, as a factor of current industrial technogenesis, was also assessed. Analysis of wastewater samples was carried out for organoleptic, hydrochemical and microbiological indicators in accordance with the methods of interstate standard 24849-2014 [2].

\section{Results and discussion}

\subsection{Newly formed soils in the bottoms of sugar wastewater lagoons: diagnostics and properties}


Natural soil-forming rocks in the bottoms wastewater lagoons of disposal fields from operational sugar refinery in Lgov are loess-like carbonate loam, heavily transformed with the influence of sugar refineries wastewater. Along with the chemical influence of wastewater, great amount of conveyor-washing and filtration sludge is deposited here even under periodical mechanical cleaning. Transporter-washing sludge formed during sedimentation of trap, sugarbeet-washing and elevator wastewaters in settling tanks consists mainly of fine-grained humus horizons of agrosulfuric and agro-chernozem soils with an admixture of sugarbeet root debris, stems, and leaves. The technogenic effect of filtration sludge on substrates and soils is determined by its high content of carbonates, organic matter, nutrients [3].

Newly formed soils of the sugar wastewater lagoons of the operating sugar refinery are referred to organic-accumulative alkaline phyto-zooturbated hydrometamorphosed soils, which fit neither into the cells of the Soil Classification of Russia [4] nor WRB scheme [5]. Obtained analytic results allow to specify some unique properties common to these soils. The upper soil horizons are characterized by intensive staining with humus, heavy- and medium-loam composition, good texture and porosity, signs of active biota activity and a relatively small amount of artifacts (debris of construction and household waste). There is a shift of $\mathrm{pH}$ values to alkaline (8.3-8.9) in soils in comparison with background soils of the region (Luvic (Anthric) Chernozems), formation of pedogenic carbonates $\left(\mathrm{CaCO}_{3} 11-39 \%\right)$ and phosphates, increased content of organic carbon (2.28-2.46), mobile forms of phosphorus (up to $229.0 \mathrm{mg} / \mathrm{kg}$ ), potassium (404.0-648.4 mg/kg) and easily hydrolysable nitrogen $(148.5-183.0 \mathrm{mg} / \mathrm{kg})$.

On completely abandoned and recultivated disposal fields of closed Peny's sugar refinery soil-forming rocks are represented by sandy loam alluvial deposits of the second terrace of Seim river. Under sparse grasslands dominated by Calamagróstis epigéjos greyhumus medium-loam soils are formed, referred to the soil subtype overcompacted with signs of illuviation of organic-ferrous compounds. According to WRB classification [5] these soils are indicated as Calcaric Someric Phaeozem (Siltic, Densic, Transportic). Their $\mathrm{pH}$ values (8.2-8.4) indicate an alkaline soil solution. The content of carbonates in such soils $(0.5-2 \%$ - slightly carbonate) is much lower than in the soils of operative disposal fields from Lgov's sugar refinery. The provision of the upper horizons with organic carbon is also low $(0.77 \%)$.

\subsection{Quality of wastewaters from the currently operational sugar refinery}

Wastewaters of the operating sugar factory have a characteristic putrid smell; they are characterized with neutral and weakly alkaline reaction, high content of ammonia and ammonium salts $(4.9 \mathrm{mg} / \mathrm{dm} 3)$, deficit of nitrites $\left(0.01 \mathrm{mg} / \mathrm{dm}^{3}\right)$ and nitrates $\left(1.1 \mathrm{mg} / \mathrm{dm}^{3}\right)$. Chemical Oxygen Demand (COD) assessed by the permanganate method and considered one of the most informative indicators of anthropogenic water pollution by organic compounds, is twice higher $\left(9.8-10.4 \mathrm{mgO}_{2} / \mathrm{dm}^{3}\right)$ than that of drinking water. In wastewater from active sugar industry, heavily contaminated with organic compounds, a significant total amount of bacteria is recorded, and it is 16-40 times higher than the standards of 100 $\mathrm{CFU} / \mathrm{ml}$.

\subsection{Soil microbiota of disposal fields from sugar refineries}

The number of microorganisms in studied newly-formed soils of disposal fields from the active sugar refinery is much higher than in the background Luvic (Anthric) Chernozem (Fig. 2). The microbiological processes of organic matter degradation proceed with high intensity mainly due to bacteria $(1.9-4.8 \mathrm{mln}$. CFU/g) with insignificant number of 
Actinomycetes and especially Micromycetes amounting to less than $100 \mathrm{CFU} / \mathrm{g}$. The lower amount of Actinomycetes and Micromycetes against the amount of other microorganisms is associated with the increased humidity of the substrate of wastewater lagoons. Mycelial type of growth and development of these groups of microbiota is an adaptation to dwelling in solid-phase substrate and suggests functioning of organisms in aerobic conditions, which may be the reason for their low activity under periodic waterlogging of wastewater lagoons with the formation of dense plant cover of Phragmites austrális or Filipéndula vulgaris. Only for oligotrophic microorganisms, non-demanding for nutrients and indicating the final stages of microbial succession, present in the surface horizon of the organic-accumulative soil under Phragmites austrális, saturated with plant residues of various degrees of decomposition, the number was recorded at the same level compared to the background soils.

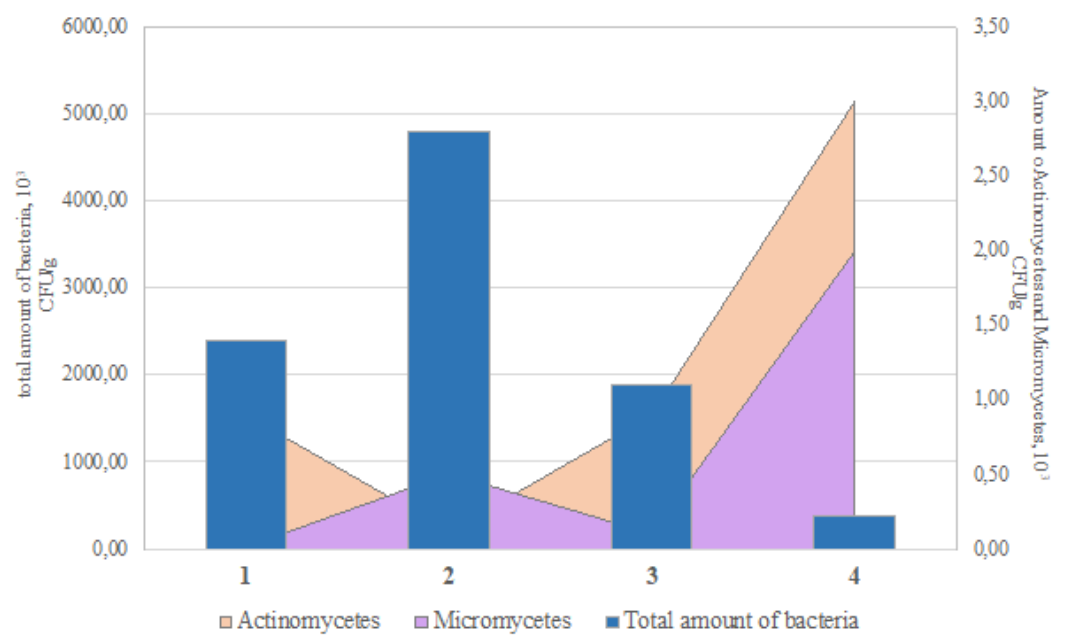

Fig. 2. Total amount of bacteria $\left(10^{3} \mathrm{CFU} / \mathrm{g}\right)$, amount of Actinomycetes and Micromycetes $\left(10^{3} \mathrm{CFU} / \mathrm{g}\right.$, along the right axis) in newly-formed soils of disposal fields from operative Lgov's sugar refinery (13 ) and in background soils (4).

In the newly formed soils of the recultivated and abandoned disposal fields from Peny's sugar refinery, the number of Actinomycetes was higher in comparison to the background soils, whereas the content of Micromycetes was recorded at the same level as in the background soils (Fig. 3).

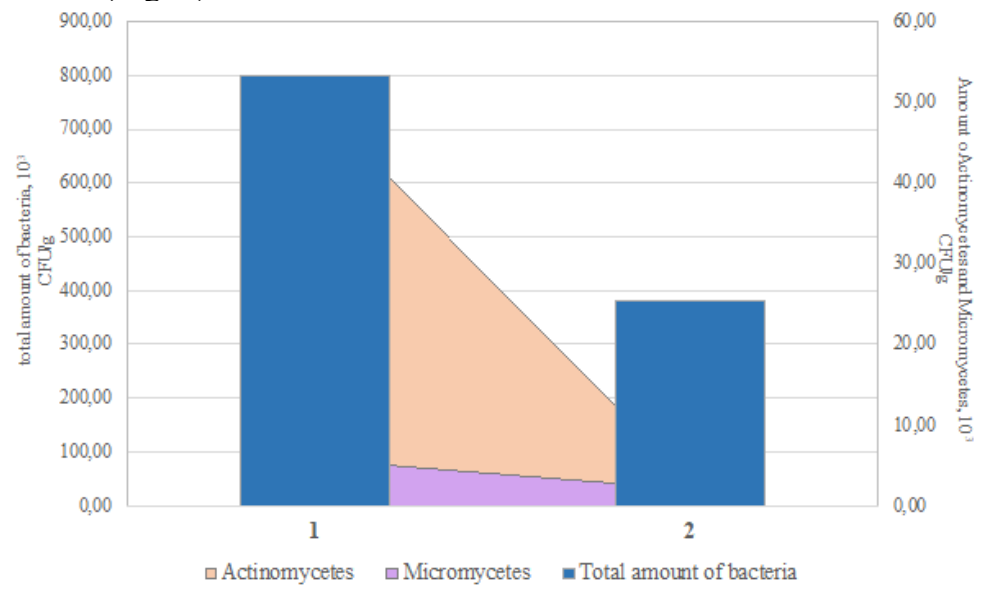


Fig. 3. Total amount of bacteria $\left(10^{3} \mathrm{CFU} / \mathrm{g}\right)$, amount of Actinomycetes and Micromycetes $\left(10^{3} \mathrm{CFU} / \mathrm{g}\right.$, along the right axis) in newly-formed soils of disposal fields from abandoned sugar refinery (1) and background soils (2).

The detected high proportion of Actinomycetes in the prokaryotic complex of microorganisms in soils of abandoned and recultivated sugar wastewater lagoons is associated with the high alkalinity of gray-humus horizons, limiting the accessibility of nutrients for Actinomycetes. The low proportion of Actinomycetes is also pointed out as a distinctive feature of the microbiological community for urban soils [6].

\section{Conclusions}

The number of microorganisms in the newly-formed soils of disposal fields from the active sugar factory is much higher than in the regionally background soils, which indicates more intensive processes of organic matter destruction in complexes of sugar wastewater lagoons, accompanied by emission of carbon dioxide, and in anaerobic conditions - by emission of methane.

For the soils formed on abandoned long time unused disposal fields, withdrawn from circulation more than 20 years ago, slowing down of microbiological processes was noted under the preserving high alkalinity in surface soil horizons.

The study is supported by Russian Foundation for Basic Research (RFBR), grant № 19-29-05025-mk.

\section{References}

1. S. Thiele-Bruhn, M. Schloter, B.-M. Wilke, L.A. Beaudette, F. Martin-Laurent, N. Cheviron, C. Mougin, J. and Römbke, SOIL, 6, 17-34, (2020).

2. GOST 24849-2014. Interstate Standard. Water. Methods of sanitary-bacteriological analysis for field conditions [in Russian], 46 (2016)

3. L.N. Puzanova, T.I. Sysoeva, Agroecological Problems of Soil Science and Farming. Proceedings of the International Scientific-Practical Conference of Kursk Branch of MOO Society of Soil Scientists named after V.V.Dokuchaev [in Russian], 319-321 (2019)

4. L.L. Shishov. V.D. Tonkonogov. I.I. Lebedeva, M.I. Gerasimova (Eds.) Classification and Diagnostic System of Russian Soils [in Russian] (Oikumena, Smolensk, 2004)

5. IUSS Working Group WRB. World Reference Base for Soil Resources 2014, update 2015 International soil classification system for naming soils and creating legends for soil maps, World Soil Resources Reports, 106 (FAO, Rome, 2015), 203

6. N. Stepanov, A. Manucharova, V. Smagin, A. Kurbatova, A. Myagkova, V. Bashkin, Eurasian J. Soil Sci., 38, 864-869 (2005) 